\title{
Т.Б. Фрик
}

\section{ОБРАЗ «ЧУЖОГО» В ЭПИСТОЛЯРИИ Н.М. КАРАМЗИНА ${ }^{1}$}

\begin{abstract}
Статья посвящена осмыслению образа «чужсого» в письмах Н.М. Карамзина к разным адресатам. Карамзинский эпистолярий рассматривается как значимая часть творческого наследия его автора. Сделан вывод о том, что образ «чужого» явлен на уровне образной и мотивной организации, в пространстве писем он неотделим от образа «своего» и неразрывно связан с карамзинской политической педагогикой и нравственно-философскими идеалами.

Ключевые слова: Н.М. Карамзин, эпистолярий, образ «чужсого», поэтика эпистолярия.
\end{abstract}

В контексте отечественной культуры проблема восприятия и осмысления «чужого», безусловно, имеет особое значение, поскольку одним из основных смыслов интереса к «чужому» в России традиционно является самопознание [1. С. 160]. Применительно к указанной проблематике обращение к Н.М. Карамзину как к личности и автору «Писем русского путешественника», «Истории государства Российского» и переводчику стало уже своеобразной традицией. Это обстоятельство объясняется, с одной стороны, ролью Н.М. Карамзина в процессах смены эстетического сознания эпохи, в изменениях в подходах к воплощению действительности средствами литературы, с другой - значимостью его творчества для решения проблемы самоопределения русской культуры относительно культуры западной. Так, по мысли Б.А. Успенского и Ю.М. Лотмана, роль Н.М. Карамзина заключается в упразднении противопоставления миров России и Европы: «"Письма русского путешественника" были принципиально новым словом в споре о России и Западе. Карамзин вводил читателя в мир, где Россия и запад не противостояли друг другу. Европа $<\ldots>$ стала обыкновенной, понятной, своей, а не чужой» [2. С. 564]. В меньшей степени с этой точки зрения в контекст исследовательских размышлений попадает эпистолярное наследие Н.М. Карамзина, в связи с чем рассмотрение частных писем писателя в указанном аспекте представляется значимым и актуальным.

Предваряя выводы, касающиеся специфики образа «чужого» в эпистолярии Н.М. Карамзина, необходимо сделать несколько вводных замечаний. В современной исследовательской практике выделяется подход к писательскому эпистолярию как к разновидности дискурса, отражающего высокую степень самораскрытия личности, имеющего серьезное влияние на

\footnotetext{
${ }^{1}$ Исследование выполнено в Томском политехническом университете в рамках Программы повышения конкурентоспособности Томского политехнического университета.
} 
общество как на философский, историософско-антропологический нарратив человека во времени и времени в человеке [3. С. 4]. Кроме того, особенно письма писателей рубежа XVIII - начала XIX в., рассматриваются как неотъемлемая часть художественного наследия их авторов. С этой точки зрения вполне закономерно стремление исследователей осмыслить частную переписку Н.М. Карамзина как явление культуры и литературы, в этом смысле высказывание П.А. Вяземского по-прежнему не теряет своей актуальности: «В них (письмах. - T.Ф.) старший памятник и жизни его, и литературного нашего преобразования $<\ldots>$ В них специально ничему не научишься, но вместе с тем научишься всему, что облагороживает ум и возвышает душу» [4. С. 251-252].

Рост интереса к наследию Карамзина как к живому факту отечественной культуры стал причиной появления ряда работ, направленных на осмысление его частной переписки как явления культурного и как факта литературы. Анализ поэтики карамзинских писем позволяет вскрыть их философско-антропологический, культурно-исторический и художественный потенциал. Н.М. Карамзин в своей эпистолярной практике воплотил совершенно новую для своей эпохи структуру нарратива, характеризующегося своеобразным типом взаимосвязи литературной практики и жизни, он «олицетворил новый тип мироощущения, новый тип личностной структуры, художественного поведения, трансформации человеческого опыта в структуру литературного текста» [5. С. 127]. В частной переписке писателя расширяются границы документальности посредством принципов и приемов художественного осмысления действительности, письма раскрывают не только внутренний мир автора, но и «процесс формирования индивидуально-авторской модальности в русской словесности» [6. С. 127].

Форма и идейное наполнение писем, явленный в них мотивный комплекс, ключевые образы, субъектная организация эпистолярия отразили характерные для Карамзина способы олитературивания действительности, принципы организации эпистолярного диалога с адресатом, в котором в ряду прочего особым образом осмысляются соотношения «свое» - «чужое», Россия - Европа, «мы - они».

Теснейшая связь внутренней жизни Карамзина с литературой определяет образную структуру писем. В них выкристаллизовывается сложный авторский образ, отражающий различные уровни саморефлексии биографического автора писем. Можно с достаточной долей уверенности утверждать, что для писателя характерно специфическое эпистолярное поведение, в основе которого лежат особые стратегии авторской самопрезентации. В этом смысле проблема сочетания субъективного и объективного слоев карамзинского повествования, взаимодействие плана автора и плана героя, персонифицированного повествователя с биографическим автором текста, крайне актуальная при осмыслении писательского нарратива [7. C. 5-6], не менее важна и при анализе его эпистолярного наследия, в том числе в аспекте отражения в нем проблематики и поэтики «своего» и «чужого». 
Эта особенность карамзинской эпистолярной практики проявляется еще в ранних письмах. В частности, в письмах к Лафатеру (речь идет о переписке Н.М. Карамзина и швейцарского философа в 1786-1790 гг.) образ автора - это образ пылкого русского юноши, раскрытие и позиционирование которого происходит относительно других культур, и воплощением этого своеобразного культурного трансфера становится именно эпистолярная форма: «Знаете ли вы, что один русский юноша имел счастие читать ваши сочинения < ..> О, если б я мог увидеть этого человека! < ..> Но как это возможно? Отделенный от него несколькими странами, я никак не надеюсь на такое счастие. Но не могу ли я написать к нему письмо? $<\ldots>$ Юноша не хочет терять ни одной минуты, берет перо в руки и начинает писать свое письмо. Этот юноша - я сам, и так, как я юноша, то вы должны меня простить, что я своим письмом прерываю более важные занятия ваши [8. С. 236]. Показателен в этом смысле и постскриптум письма: «Простите мне все ошибки языка <..> ведь я не немец и ни с кем еще не обменивался немецкими письмами» [Там же. С. 237].

Карамзин выстраивает эпистолярное общение с Лафатером как переписку ученика и великого учителя, однако при этом совершенно очевидно, что за ученической маской в переписке с Лафатером-учителем стоит автор писем глубоко мыслящий, начитанный и ироничный, способный на самостоятельные оценки. Так, в цитируемом выше письме находим достаточно категоричное высказывание относительно памфлета Мирабо, направленного против Лафатера: «Пусть сумасбродный француз кричит до изнеможения легких. Всякий разумный человек согласится, что французы - сумасброды» [Там же. С. 237, 238]. При этом появление образа сумасбродного француза необходимо рассматривать как способ усиления интенции письма (создание восторженного образа Лафатера - учителя), а не как проявление некой мировоззренческой константы.

Подобный прием Н.М. Карамзин будет использовать и в более поздних своих письмах. В этом смысле характерным примером может служить фрагмент из письма к М.Н. Муравьеву от 28 сентября 1803 г., в котором адресант, прося помощи последнего в получении должности придворного историографа, позиционирует себя как автора европейского уровня, апеллирует к европейскому культурному опыту, рассматривая его в качестве образца для подражания: «Правительство может иметь некоторое уважение к человеку, который способствует успехам языка и вкуса, заслужил лестное благоволение российской публики и которого безделки напечатаны на разных языках Европы, удостоились хорошего отзыва славных иностранных литераторов <..> Во Франции, богатой талантами, сделали некогда Мармонтеля историографом и давали ему пенсию, хотя он и не писал Истории: у нас в России, как вам известно, не много истинных авторов... для чего же, казалось бы, не поддержать автора, уже известного в Европе»? [Там же. С. 280-281].

Интересен также круг чтения, отсылки к которому в переписке с Лафатером часто становятся для Карамзина - автора писем источником раз- 
мышлений о проблемном поле Россия - Европа, за которыми стоит просвещенный, оригинально мыслящий русский, берущий на себя право встраивать русских авторов в парадигму европейской культуры: «Я читаю произведения Лафатера, Гелерта, Галлера и многих других. Я лишен удовольствия много читать на своем родном языке. Мы еще бедны писателями. У нас есть несколько поэтов, заслуживающих быть читанными: первый и лучший из них - Херасков <..> 14 лет тому назад господин Новиков прославился своими остроумными сочинениями $<\ldots>$ В господине Ключареве мы имеем поэта-философа, но он пишет немного» [8. С. 242]. В качестве примера работы Карамзина - автора писем по созданию образов автора и адресата, смены образных планов можно также привести фрагмент письма от 10 июня 1788 г., посвященный размышлениям о сочинениях Беннета: «Вы ведь мой учитель - сердце мое трепещет от этого радостного сознания. - Ученик ваш поэтому должен сообщить вам, чем он занимается. Я прилежно читаю сочинения Беннета»; далее образный план меняется: «Хотя великий философ нашего времени открыл мне много новых взглядов, я все-таки не вполне доволен всеми этими гипотезами»; в итоге после глубокого философского пассажа автор вновь скрывается за ученической маской: «Может быть... но я слишком много болтаю. <..> Будьте здоровы, мой благодетель» [Там же. С. 251].

Образ автора, как и образ адресата, в дальнейшем также определяет характер карамзинских писем, влияет на их имагологию. В письмах разных лет к друзьям, членам семьи, монаршим особам, чиновникам, литераторам в ряде вербализуемых поведенческих максим выкристаллизовываются различные авторские образы: сельский житель, стареющий историограф, философ, меланхолик, варвар, гурон (человек, чужой светской жизни и ее законам). Все эти образы, с одной стороны, отражают влияние литературной традиции, с другой - фиксируют жизненную философию, просветительские и педагогические принципы Н.М. Карамзина. Так, в письмах к царствующим особам автор писем и наставник, ментор, просветитель (для императрицы Елизаветы Алексеевны он «высший трибунал в области русского языка», для сестры императора Александра I Екатерины Павловны «милый учитель», «учитель любимый»), и гражданин, пылающий «ревностию ко славе отечества» [Там же. С. 281].

Осмыслению и трансляции собственного мироощущения, выстраиванию поведенческого текста также способствуют инокультурные образы, одним из которых, в частности, становится образ Дон Кихота, самоотождествление с ним высвечивает значимые грани образа умудренного жизнью историографа, последовательно создаваемого Карамзиным в его письмах: «Назови меня Дон-Кишотом; но сей славный рыцарь не мог любить Дульцинею свою так страстно, как я люблю - человечество!» [Там же. С. 369]. Исследователи справедливо отмечают связь испанской темы в карамзинском наследии с эволюцией его мировоззрения как писателя и историографа [9. С. 113], в эпистолярном контексте образ Дон Кихота принципиален для выражения гуманистических идей содействия благу 
всего человечества, патриотизма, всемирной отзывчивости, он стал своеобразной квинтэссенцией идеалистических установок автора.

Образ «чужого» по-особому раскрывается и в мотивной структуре карамзинского эпистолярия, в частности в мотиве родного края, который стал для Н.М. Карамзина - автора писем мотивом всей жизни. Раскрытие данного мотива осуществляется средствами сентименталистской эстетики и поэтики и актуализирует движение эпистолярного нарратива от быта к нравственной и философской символике. Мотив родного края, нашедший отражение в письмах, фиксирует ценностно значимые смыслы, становится символом духовной связи, единства автора с его адресатом (земляком, родственником, другом). Он имеет реальную топографическую привязку: Знаменское, Симбирск, Волга, Свияга, заволжские деревни - пространства, единящие Н.М. Карамзина со старшим братом В.М. Карамзиным, земляками И.И. Дмитриевым и А.И. Тургеневым. В переписке с братом родной край - это пленительное воспоминание, символ неразрывной связи с домом и семьей, малой родиной, способ единения с родными; в письмах Н.М. Карамзина к И.И. Дмитриеву малая родина - это идеальный топос дружбы земляков, поэтов, сочувственников. Не менее важную роль в карамзинском эпистолярии играет образ Москвы, противопоставленной официальному Петербургу. Москва и Петербург Карамзина, очевидно, не просто вписываются в поэтику и эстетику петербургского и московского текста русской литературы, но и играют не последнюю роль в их сотворении.

Важно все же, что образ родного края и его значимость не ограничиваются только указанными выше субъективно ценными для Карамзина топосами. Своеобразная философия «чужого» пространства также становится инструментом жизнестроительства автора писем, способствует декларации его системы ценностей. В этом смысле чрезвычайно показательным является польский сюжет, развернувшийся в переписке Н.М. Карамзина и князя П.А. Вяземского в период с 1817 по 1821 г. (время службы последнего в канцелярии комиссара императора Н.Н. Новосельцева в Польше).

Исследователи отмечают своеобразный национализм Н.М. Карамзина (слово «национализм» прежде всего фиксирует «круг идей, связанных с новым восприятием государства» [10. С. 72]), отразившийся в стремлении обнаружить исконно русскую самобытность, в фиксации принципиальной значимости самодержавия для российской государственности, утверждение идеи государственного могущества страны как гаранта ее безопасности. В этой связи не случайно сложное отношение Карамзина-историка к польскому вопросу, выразившееся и в записке Александру I («Мнение русского гражданина»), и в «Истории государства Российского» и заключающееся в неприятии расширения польских границ за счет присоединения западных губерний и ее особого статуса в составе Российской империи. Все это не могло не отразиться в дружеской переписке, в которой, однако, образ «чужой» Польши явно усложняется.

Изначально в письмах к П.А. Вяземскому Польша (Варшава) - пространство чужое и чуждое, все, что с ним связано, воспринимается нега- 
тивно, сам факт отъезда Вяземских вызывает только отрицательные эмоции у Карамзина: «Вам, как видно, рок ехать в Варшаву, хотя у меня по сие время и не лежит к этому сердце» [8. С. 317]; «Тамошняя скука ваша есть добродетель в моих глазах: мне бы грустно было, если бы вы веселились с поляками, хотя мы и должны любить их по Христианству и человечеству» [Там же. С. 326]. Однако контекст карамзинского дружеского письма, создаваемый с опорой на систему категорий чувствительной литературы, ориентированный на поэтизацию дружеских уз, связывающих автора и адресата, способствует присвоению чужого и чуждого пространства, смене оценочного регистра: «Вы завезли туда и наше сердце. Польша сделалась нам своя: чего не бывает на свете?» [Там же. С. 322]; «Краков не Рим, однако ж имеет свои древности, и притом славянские: можно видеть их с любопытством и удовольствием» [Там же. С. 328].

В рамках польского сюжета родной край - это вся Россия, которая представляет пространство сакральное, не случайно в этом отношении приветствие Карамзина, адресованное Вяземскому: «От всего сердца обнимаем вас, любезный князь на Святой Руси» [Там же. С. 333]. Сакрализация «своего» пространства усиливается за счет включения библейских контекстов: «Хорошо во всяком месте оставить людей с добрым об нас мнением. Вопреки библейской пословице можно быть пророком и в своей земле; однако ж добрая слава и в чужой лестна сердцу» [Там же. С. 340].

Так образ родного края - пространства субъективно значимого - разрастается до образов-символов: Святая Русь, своя земля, дом, которые вписаны в контекст историко-философских представлений автора писем, а также его размышлений о любви к родине, о долге перед отечеством. Здесь уместно вспомнить один из фрагментов карамзинской записки «О любви к отечеству и народной гордости»: «Любовь к отечеству может быть физическая, моральная и политическая <... Н Но физическая и моральная привязанность к отечеству, действие натуры и свойств человека не составляют еще той великой добродетели, которою славились греки и римляне. Патриотизм есть любовь ко благу и славе отечества и желание способствовать им во всех отношениях» [11. С. 280-281]. В своей эпистолярной практике Н.М. Карамзин последовательно развивает эту мысль, внедряет ее в сознание адресата.

В письмах к П.А. Вяземскому и А.И. Тургеневу периода их жизни за границей образ России-дома противопоставлен Н.М. Карамзиным всему европейскому - чужому. Не случайно в замечании по поводу отъезда А.И. Тургенева содержится сдержанное, но вполне явное осуждение: «Он (А.И. Тургенев. - Т.Ф.) смотрит от нас в лес. То есть в Европу; а мы остаемся мыкать азиатское свое горе в уединении» [8. С. 351]. А в письме от 6 сентября 1825 г. к самому Тургеневу Карамзин-наставник, напоминая своему адресату о необходимости вернуться на родину, в полной мере раскроет свои представления о патриотизме через образы «своего» (реального, истинно ценного, требующего приложения созидательных усилий) и «чужого» (эфемерного, отвлекающего от настоящего дела): «Все чужое 
есть для нас только зрелище: смотри, а дела не забывай! Вы еще в долгу у России. То есть уже напоминаю Вам о возвращении... "В дому Моем многие обители суть" < ..> Для нас, русских с душою, одна Россия самобытна, одна Россия истинно существует: все иное есть только отношение к ней, мысль, привидение. Мыслить, мечтать можем в Германии, Франции, Италии, а дело делать единственно в России, или нет гражданина, нет человека: есть только жвачное животное с брюхом и с знаком пола, в навозе, хотя и цветами убранном» [8. С. 435].

Сентиментальная картина мира с характерными для нее вчувствованием и психологической интеграцией с окружающими реалиями, значимостью образа «Другого», диалогического взаимодействия с ним влияет и на характер отражения особенностей нациестроительства, в процессе которого большую роль играет общность сердечных порывов [12. С. 9-10], оказывает серьезное воздействие на поэтику писем Н.М. Карамзина вообще и поэтику «чужого» в частности.

Карамзинский эпистолярий отразил меланхолическую традицию русской сентиментальной культуры, вобрал поэтику лирического автобиографизма. Письма, пронизанные элегическими мотивами, посредством которых передается предметное содержание, зафиксировали характерную авторскую манеру, в которой проявилось его стремление к закреплению взаимосвязи внутреннего мира адресанта с переживаемыми реалиями и событиями внешнего мира.

Особую роль в создании лиризма играют итальянские мотивы и образы, появление которых часто напрямую связано с поэтизацией фрагментов письма, в которых частная, бытовая ситуация возводится на уровень лирической философии. Примером может служить переписка Н.М. Карамзина с вдовствующей императрицей Марией Федоровной. Одним из центральных образов их эпистолярного общения становится образ Розового павильона - символа долгожданной встречи императрицы и историографа: «Не завидую ни Капитолию, ни Петрарке, ни Тассу; не возьму их свежих лавровых венков за одну иссушенную розу всего волшебного Павильона, которая упала с неба в тихий, уединенный кабинет мой: храню ее как святыню среди Клийских хартий и свитков; она уже не завянет и служит для меня эмблемою исторического бессмертия» [8. С. 33]. Мотив отсутствия зависти в данной ситуации также крайне важен, поскольку маркирует границу между «своим» и «чужим», при этом последнее усиливает идилличный образ близкого автору пространства.

Образ солнечной Италии еще не раз появится в письмах как часть поэтичных картин родной природы, как средство поэтизации родного края, способ выражения патриотических чувств: «...один день лучше другого, и мы в гордости своей не завидуем солнцу Италии: Царскосельское, Павловское так ярко, что русская пословица: смотреть сентябрем на сей раз не имеет смысла. Наслаждаемся и надеемся: барометр поднимается непрестанно выше и выше, как Россия!» [Там же. С. 42].

В поздних письмах Н.M. Карамзина образ Италии развивается в рамках элегической традиции. Италия прекрасна и недостижима, она символ но- 
вой жизни и перемен для больного историографа: «...я имею неописанную жажду к разительно новому, к другим видам природы, горам, лазури италианской еtс. ... Мне не верится, что буду на море еtс» [8. С. 356]; «Мысли стремятся во Флоренцию» [Там же. С. 357].

Один из ключевых элегических мотивов карамзинских писем - это мотив оживления через рассказ, или воспоминание, воплощенный в совокупности с мотивом ожидания и невозможности встречи. Он сближает поэтику эпистолярия с поэтикой стихотворного дружеского послания. Так, мысленно переносится к Лафатеру русский юноша - Карамзин: «Меня приводило в восторг переноситься мысленно в Цюрих, воображать себя в одной стране, под одной кровлей с Лафатером, - в этой мечте для меня было чтото существенное» [Там же. С. 248]. Также мысленно за своим августейшим адресатом - императрицей Марией Федоровной - Карамзин-историограф переносится из России в Германию, объединяя в своем воображении и тексте письма обе державы в общее пространство дружбы и единения родных сердец, не забывая напомнить адресату об истинной его миссии: «Вы уже далеко; но мы не перестаем следовать за Вами душою и сердцем. Оставив страну, ознаменованную Вашими благотворениями, видите ту, которая славится Вашим рождением. Германия - сестра России. Вы утвердили сою3 между ими <..> Место родины всегда приятно для души чувствительной, но место, где мы делаем добро, еще приятнее. Вы должны любить Германию: не завидуем ей, ибо Вы любите Россию еще более и не можете воспоминать о ней без умиления» [Там же. С. 42]. Так в очередной раз мотивы своего и чужого пространств стали отражением мировоззрения Карамзина, его жизненных принципов.

Очевидно, что образ «чужого» в пространстве карамзинских писем неотделим от образа «своего», от мыслей о судьбе России, он неразрывно связан с карамзинской политической педагогикой и нравственнофилософскими идеалами. Рассмотрение эпистолярия Н.М. Карамзина через призму образа «чужого» позволяет высветить значимые аспекты мировоззрения автора писем, рассмотреть динамику проявившихся в эпистолярии характерных элементов поэтики, которая определяется жизненной и творческой траекторией писателя. Карамзинские письма представляют собой пример того, как эпистолярный текст взаимодействует с литературной традицией, участвует в творческой деятельности его автора и, что немаловажно, становится продуктивным для развития отечественной прозы вообще и эпистолярной в частности, оказывает влияние на развитие национального сознания.

\section{Литература}

1. Лотман Ю.М. Современность между востоком и западом // Знамя. 1997. С. $157-$ 169.

2. Лотман Ю.М., Успенский Б.А. «Письма русского путешественника» Карамзина и их место в развитии русской культуры // Карамзин Н.М. Письма русского путешественника. Л., 1984. С. 525-606. 
3. Сапожникова Н.В. Философско-антропологическая природа эпистолярного дискурса : автореф. дис. ... д-ра филос. наук. Екатеринбург, 2004. 46 с.

4. Вяземский П.А. О письмах Карамзина // Вяземский П.А. Эстетика и литературная критика. М., 1984. С. 250--253.

5. Шаврыгин C.M. Особенности художественного мироощущения Н.М. Карамзина // Карамзинский сборник: Наследие Н.М. Карамзина и современное развитие российского общества. Ульяновск, 2014. С. 127-129.

6. Сапченко Л.А. «Любовные письма совсем не принадлежат к письмам...» (специфика жанра в эпистолярии Н.М. Карамзина) // Ученые записки Казанского университета. Серия гуманитарные науки. 2016. Т. 158, кн. 1. С. 167-182.

7. Лебедева О.Б. Alter ego как имагологический объект: нарративная структура «Писем русского путешественника» Н.М. Карамзина в свете национальной повествовательной традиции // Имагология и компаративистика. 2015. № 1 (3). C. 5-28. DOI: $10.17223 / 24099554 / 3 / 1$

8. Карамзин Н.М. Полное собрание сочинений : в 18 т. Т. 18: Письма. М. : ТЕРРАКнижный клуб, 2009. 624 с.

9. Сапченко Л.А. «Гишпанцам желаю добра...»: (Н.М. Карамзин и Испания) // Вестник МГОУ. Серия: Русская филология. 2015. № 6. С. 106-114.

10. Летняков Д.Э. Н.М. Карамзин и зарождение националистического дискурса в России // История философии. 2016. Т. 21, № 1. С. 72-86.

11. Карамзин Н.М. О любви к отечеству и народной гордости // Избранные сочинения : в 2 т. М. ; Л., 1964. Т. 2. С. 280-287.

12. Анисимов К.B. Восточный травелог русской литературы XIX в.: «воображение» имперских окраин и поэтика повествования (предварительные замечания) // Имагология и компаративистика. 2014. № 1 (10). C. 5-21. DOI: 10.17223/24099554/1/1

\section{The Image of the "Alien" in Epistolary Works by Nikolay Karamzin}

Vestnik Tomskogo gosudarstvennogo universiteta. Filologiya - Tomsk State University Journal of Philology. 2020. 63. 305-314. DOI: 10.17223/19986645/63/18

Tatyana B. Frik, Tomsk Polytechnic University (Tomsk, Russian Federation). E-mail: tfrik@tpu.ru

Keywords: Nikolay Karamzin, epistolary works, image of "alien", poetics of epistolary works.

The research is supported by Tomsk Polytechnic University within the framework of Tomsk Polytechnic University Competitiveness Enhancement Program.

The article is aimed at understanding the image of the "alien" in Nikolay Karamzin's letters to different addressees. Epistolary works are considered as a significant part of Karamzin's creative heritage. The author of the work states the fact that the writer's private correspondence expands the boundaries of documentariness through the principles and techniques of an artistic understanding of reality; therefore, the form and ideological content of the letters, the motivational complex manifested in them, the key images, their subjective organization reflect Karamzin's characteristic methods of a literary presentation of reality, the organization principles of an epistolary dialogue with the addressee, in which the connection between "own" and "alien", Russia and Europe, "us" and "them" are comprehended among other things. Various levels of Karamzin's self-reflection are given through the correlation of "own" and "alien", as well his specific epistolary behavior, which is based on special strategies of the author's self-presentation. The image of the author, like the image of the addressee, the character of Karamzin's letters, influence their imagology. Foreign cultural images, one of which in particular is Don Quixote, which is an expression of humanistic ideas promoting the welfare of all humankind, patriotism, worldwide responsiveness, a kind of quintessence of the author's idealistic attitudes, also contribute to the comprehension and translation of his own worldview. The image of the "alien" is revealed in a special way in the 
motive structure of Karamzin's letters, in particular, in the motive of the native land. At the same time, the philosophy of the "alien" space becomes an instrument for the life-building of the author of the letters, contributes to the declaration of his value system: "own" (holy Russia, Fatherland, home) is truly valuable, it requires constructive endeavour, "alien" is ephemeral, distracting from real things. Obviously, the image of the "alien" in Karamzin's letters is inseparable from the image of the "own", thoughts about the fate of Russia; it is inextricably linked with Karamzin's political pedagogy and moral and philosophical ideals. The consideration of Karamzin's letters through the prism of the image of the "alien" makes it possible to highlight significant aspects of the author's worldview, consider the dynamics of characteristic elements of his poetics that appear in the letters and are determined by the writer's life and creative way. Karamzin's letters represent an example of how an epistolary text interacts with the literary tradition, participates in the creative activity of its author, and, not at least, becomes productive for national prose development in general and epistolary works in particular, how it influences the development of national consciousness.

\section{References}

1. Lotman, Yu.M. (1997) Sovremennost' mezhdu vostokom i zapadom [Modernity between East and West]. Znamya. 9. pp. 157-169.

2. Lotman, Yu.M. \& Uspenskiy, B.A. (1984) "Pis'ma russkogo puteshestvennika" Karamzina i ikh mesto v razvitii russkoy kul'tury ["Letters of a Russian Traveler" by Karamzin and their place in the development of Russian culture]. In: Karamzin, N.M. Pis'ma russkogo puteshestvennika [Letters of a Russian Traveler]. Leningrad: Nauka. pp. 525-606.

3. Sapozhnikova, N.V. (2004) Filosofsko-antropologicheskaya priroda epistolyarnogo diskursa [The philosophical and anthropological nature of the epistolary discourse]. Abstract of Philosophy Dr. Diss. Yekaterinburg.

4. Vyazemskiy, P.A. (1984) Estetika i literaturnaya kritika [Aesthetics and Literary Criticism]. Moscow: Iskusstvo. pp. 250-253.

5. Shavrygin, S.M. (2014) Osobennosti khudozhestvennogo mirooshchushcheniya N.M. Karamzina [Features of the artistic worldview N.M. Karamzin]. In: Shavrygin, S.M. (ed.) Karamzinskiy sbornik: Nasledie N.M. Karamzina i sovremennoe razvitie rossiyskogo obshchestva [Karamzin Collection: N.M. Karamzin's heritage and the modern development of Russian society]. Ul'yanovsk: Ilya Ulyanov State Pedagogical University. pp. 127-129.

6. Sapchenko, L.A. (2016) "Love Letters Do Not Entirely Belong to Letters..." (Specifics of the Genre in the Epistolary Heritage of N.M. Karamzin. Uchenye zapiski Kazanskogo universiteta. Seriya gumanitarnye nauki - Proceedings of Kazan University. Humanities Series. 1 (158). pp. 167-182. (In Russian).

7. Lebedeva, O.B. (2015) Alter ego as an object of imagology: the narrative structure of Letters of a Russian Traveler by N.M. Karamzin in the light of the national narrative tradition. Imagologiya i komparativistika - Imagology and Comparative Studies. 1 (3). pp. 5-28. (In Russian). DOI: 10.17223/24099554/3/1

8. Karamzin, N.M. (2009) Polnoe sobranie sochineniy: $v 18$ t. [Complete Works: In 18 Vols]. Vol. 18. Moscow: TERRA-Knizhnyy klub.

9. Sapchenko, L.A. (2015) "I wish well to the Spaniards..." (N. Karamzin and Spain). Vestnik MGOU. Seriya: Russkaya filologiya - Bulletin of the Moscow State Region University. Series: Russian philology. 6. pp. 106-114. (In Russian). DOI: 10.18384/2310-7278-2015-6-106-114

10. Letnyakov, D.E. (2016) N.M. Karamzin and the origin of nationalist discourse in Russia. Istoriya filosofii - History of Philosophy. 1 (21). pp. 72-86. (In Russian).

11. Karamzin, N.M. (1964) Izbrannye sochineniya: $v 2$ t. [Selected Works: In 2 Vols]. Vol. 2. Moscow; Leningrad: Khudozhestvennaya literatura. pp. 280-287.

12. Anisimov, K.V. (2014) The Eastern travelogue of the 19th-century Russian literature: "imagination" of imperial peripheries in the perspective of narrative poetics (introductory observations). Imagologiya i komparativistika - Imagology and Comparative Studies. 1 (10). pp. 5-21. (In Russian). DOI: 10.17223/24099554/1/1 